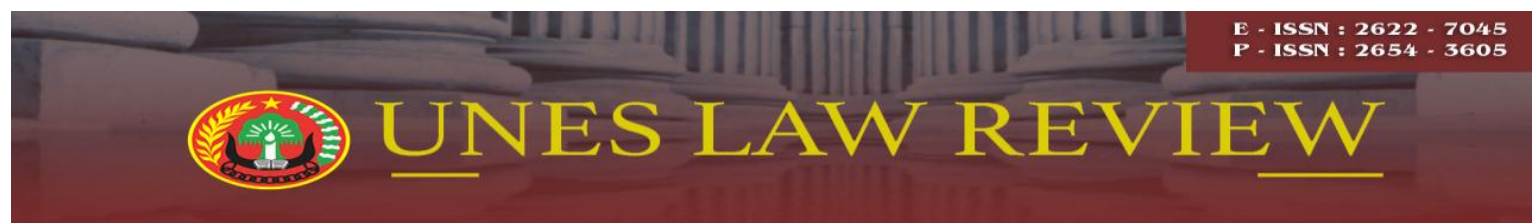

Email: uneslawreview@gmail.com

Online: http://review-unes.com/index.php/law

Volume 2, Issue 4, Juni 2020

\title{
OPTIMALISASI PERAN DIREKTORAT PENGAMANAN OBJEK VITAL POLDA SUMBAR DALAM PENANGGULANGAN TINDAK PIDANA YANG DILAKUKAN PREMAN DI OBYEK WISATA KOTA PADANG
}

\author{
Arief Suryadi \\ Program Magister Ilmu Hukum, Fakultas Hukum, Universitas Ekasakti, Padang Indonesia \\ Email: ariefsuryadi88@gmail.com
}

\begin{abstract}
Throughout 2016 to 2018 there were 29 cases of criminal acts committed by thugs in vital tourism objects in the city of Padang. Thug Handling of Tourism Objects in Padang City By Pam Obvit West Sumatra Regional Police is conducted by conducting raids or inspections by officers of the Padang City tourism area. Constraints in Tackling Thugs in Tourism Objects in Padang City By Pam Obvit West Sumatra Regional Police is a factor in human resources / lack of personnel, lack of community participation / management of attractions. Efforts Made by the Directorate of Safeguarding Vital Objects in Overcoming Barriers to Safeguarding Tourism Objects against Thugs in the City of Padang tourist area is to increase Human Resources or the Number of Police Personnel by empowering the local Bhabinkamtibmas, Increasing community participation / management of tourism objects. Optimizing the Role of West Sumatra Regional Police Obvit Pam in the Thugs Repacking in Tourism Objects in Padang City with collaborative efforts between the police and the community through police synergy where both together identify and solve the occurrence of thug problems.
\end{abstract}

Kata Kunci: Penanggulangan, Obyek Wisata, Preman, Tindak Pidana

\section{PENDAHULUAN}

Sub Direktorat Pariwisata disingkat Subdit Wisata adalah unsur pembantu pimpinan dan pelaksana utama pada Ditpamobvit yang berada di bawah Dirpamobvit. Pada Pasal 195 dan 196 Peraturan Kepala Kepolisian Negara Republik Indonesia Nomor 22 Tahun 2010 tentang Susunan Organisasi Dan Tata Kerja Pada Tingkat Kepolisian Daerah.

Di Kota Padang terdapat beberapa objek vital, seperti tempat-tempat pemerintahan, kawasan industri, kawasan pariwisata dan lain sebagainya. Salah satunya pengamanan objek vital yang difokuskan dalam penelitian ini adalah objek wisata.

Tingginya tingkat kejahatan dengan kekerasan yang terjadi merupakan ancaman dan tantangan terhadap keamanan dan ketertiban masyarakat, yang pada gilirannnya menghambat usaha pembangunan untuk mencapai kesejahteraan masyarakat. Akibat sering 
terjadinya aksi preman di tempat wisata yang ada di Kota Padang inilah menyebabkan adanya krisis kepercayaan masyarakat, banyak pihak resah dan takut, sehingga enggan untuk mengunjungi tempat tempat wisata yang ada di Kota Padang.

Menurut Bonger, dikutip oleh Abintoro Prakoso (2013:11), kriminologi adalah ilmu pengetahuan yang bertujuan menyelidiki gejala kejahatan seluas-luasnya (kriminologi teoretis atau murni). Wolfgang, dikutip oleh Wahju Muljono (2012:35), membagi kriminologi sebagai perbuatan yang disebut sebagai kejahatan, pelaku kejahatan, dan reaksi yang ditunjukkan baik terhadap perbuatan maupun terhadap pelakunya. Sedangkan etiologi kriminal (criminal etiology) adalah ilmu yang menyelidiki atau yang membahas asal-usul atau sebab-musabab kejahatan (kausa kejahatan).

Ketidak nyamanan pada tempat wisata membuat pengamanan objek vital (PAM OBVIT) semakin penting. Guna melindungi serta membuat para wisatawan merasa nyaman dan aman adalah satu tugas pokok yang harus dilakukan oleh para anggota Pengamanan Objek Vital (PAM OBVIT). Khusus dalam pengamanan tempat wisata di Kota Padang masih dinilai kurang maksimal, hal ini dapat dilihat masih banyaknya tindakan premanisme yang terjadi dan belum ada pengamanan khusus dari pihak pengamanan objek vital di tempat wisata tersebut.

Sepanjang tahun 2016 sampai 2018 terjadi 29 kasus tindak pidana premanisme di objek vital wisata yang ada di Kota Padang. Tahun 2016, tindak pidana premanisme yang terjadi di Pantai Air Manis ada sebanyak 4 kasus, di pantai Padang ada 1 kasus, di Bungus ada 1 kasus, di danau cimpago ada 1 kasus dan di pemandian ABG ada sebanyak 2 kasus. Sedangkan di tahun 2017 terjadi peningkatan ganguan preman yang terjadi di objek vital, di Pantai Air manis ada sebanyak 8 kasus, di pantai Padang ada 4 kasus, di bungus ada 1 kasus, di Danau Cimpago ada 1 kasus dan di Pemandian ABG ada sebanyak 5 kasus.

Berdasarkan latar belakang pemikiran di atas, maka permasalahan adalah upaya dan kendala dalam penanggulangan preman pada obyek wisata di kota Padang oleh Dit Pam Obvit Polda Sumbar dan Boptimalisasi peran Dit PamObvit Polda Sumbar dalam penanggulangan tindak pidana oleh preman pada obyek wisata di kota Padang. 


\section{METODE PENELITIAN}

Spesifikasi penelitian adalah deskriptif analitis, dengan metode pendekatan yuridis normative didukung oleh yuridis empiris. Jenis data yang digunakan adalah data sekunder. Data sekunder diperoleh dari studi dokumen dan studi kepustakaan. Data yang diperoleh kemudian dianalisa secara kualitatif.

\section{HASIL PENELITIAN DAN PEMBAHASAN}

Penanggulangan Preman Pada Obyek Wisata Di Kota Padang Oleh Pam Obvit Polda Sumbar

Meskipun dapat dikatakan bahwa kejahatan tersebut merupakan fenomena sosial, akan tetapi harus dapat ditanggulangi sedemikian rupa atau setidak tidaknya kejahatan tersebut terjadi/ditekan seminimal mungkin, atau pada suatu tingkat tertentu yang dapat ditolerir oleh masyarakat. Berdasarkan inilah terlihat peranan yang sangat penting dari politik kriminil, yaitu dengan cara mengarahkan semua usaha (yang rasional) untuk mengendalikan atau menanggulangi kejahatan tersebut. Usaha mana sudah barang tentu tidak hanya dengan menggunakan sarana "penal" (hukum pidana), tetapi dapat juga dengan menggunakan sarana-sarana "non-penal", bahkan dengan melalui media massa sebagai "kutub" yang lebih kecil. Dalam hal menggunakan sarana penal, tidak lain adalah dengan cara menggunakan hukum pidana sebagai sarana utamanya; baik hukum pidana materiil, hukum pidana formil maupun hukum pelaksanaan pidana yang dilaksanakan melalui Sistem Peradilan Pidana untuk mencapai tujuan-tujuan (Muladi dan Barda Nawawi Arif, 1984:18).

Keberadaan preman pada daerah wisata sudah bukanlah suatu hal yang baru. Dampak yang sering terjadi pada warga yaitu rasa tidak nyaman dan resah akan kehadiran dan tindakan premanisme seperti yang dilakukan para pengamen. Hal tersebut membuat warga menjadi merasa malas untuk pergi melakukan aktifitas di Kawasan wisata Kota Padang, atau bahkan membuat jumlah para wisatawan dari luar kota berkurang untuk berkunjung ke Kota Padang yang merupakan Pusat Kota Padang. Selain itu pula apabila tindakan premanisme yang dilakukan oleh pengamen di wilayah wisata tersebut masih terus berlanjut dan semakin bertambah pelaku tindakan tersebut, kemungkinan dapat membuat dampak yang lebih besar terhadap warga atau wisatawan. Seperti dampak terjadinya kekerasan apabila ada seorang pengamen yang dalam keadaan mabuk tidak 
terima dengan penolakan yang dilakukan warga sehingga hal itu memicu terjadinya pertikaian antara masing-masing pihak. Hal yang sangat ditakutkan dari dampak yang terjadi akibat tindakan premanisme oleh pengamen tersebut yaitu terjadinya jatuh korban oleh warga atau wisatawan, yang kemudian mengakibatkan wilayah wisata kota Padang yang sebagai Pusat Kota Padang dianggap tidak memiliki perlindungan hukum yang kuat.

Penanggulangan terhadap tindakan premanisme tersebut, perlu dilakukan baik oleh warga ataupun wisatawan serta aparat penegak hukum seperti Dit Pam Obvit Polda Sumbar. Tindakan penanggulangan yang dapat dilakukan yaitu dengan upaya penanggulangan secara "preventif" dan upaya penaggulangan secara "represif", terhadap tindakan premanisme yang dilakukan di kawasan wisata Padang.

Upaya penanggulangan preventif merupakan upaya yang sudah dilakukan selama ini. Upaya penangggulangan ini yaitu merupakan suatu upaya atau tindakan yang diambil untuk mengurangi atau menghilangkan kemungkinan terjadinya suatu kejadian yang tidak diinginkan di masa depan. Dapat diartikan secara singkat bahwa upaya penanggulangan preventif yaitu suatu bentuk pencegahan. Dalam hal ini, untuk menangani tindakan premanisme yang dilakukan oleh preman, upaya penanggulangan ini lebih tepatnya dilakukan oleh aparat penegak hukum, yaitu oleh Ditpamobvit Polda Sumbar.

Cara untuk mencegah terjadinya tindakan preman yang cenderung melakukan tindak pidana, salah satunya dengan melakukan razia atau pemeriksaan oleh petugas kawasan wisata Kota Padang. Para petugas dalam melakukan razia tersebut, tidak dilakukan secara "sidak" atau inspeksi mendadak, akan tetapi dalam melakukan kegiatan razia para petugas melakukannya secara rutin setiap hari, yang dibagi menjadi dua jam kerja yaitu dari pukul 07.00 WIB (jam tujuh pagi) hingga pukul 15.00 WIB (jam tiga sore), kemudian pukul 15.00 WIB (jam tiga sore) hingga pukul 22.00 WIB (jam sepuluh malam).

Dilakukannya razia rutin setiap hari oleh petugas ini untuk lebih menertibkan kondisi di wilayah wisata Kota Padang, terutama terhadap para pengamen yang sedang beraktivitas di sekitar wilayah tersebut. Razia yang dilakukan terkadang dibantu oleh Dinas Sosial. Kedua instansi tersebut memang saling berkaitan satu dengan yang lain, dikarenakan kedua instansi tersebut mempunyai tugas yang sama yaitu menanggulangi fenomena sosial di masyarakat, salah satunya tentang tindakan premanisme yang dilakukan oleh pengamen. Selain dengan razia setiap harinya, petugas seringkali menyarankan 
kepada masyarakat lokal maupun wisatawan untuk tidak memberikan uang kepada preman di kawasan wisata Padang. Dengan menyarankan warga atau wisatawan untuk tidak memberikan uang, secara tidak langsung akan mengurangi kehadiran preman yang ada di wilayah tersebut, kemudian secara otomatis juga mengurangi tindak premanisme.

Salah satu usaha yang telah dilakukan oleh pemerintah, antara lain dengan menyampaikan himbauan kepada masyarakat melalui pengeras suara, yang intinya berbunyi bahwa masyarakat tidak boleh memberikan uang kepada preman. Himbauan tersebut akan mudah tersampaikan kepada masyarakat.

Ada juga tindakan yang dilakukan yaitu melakukan pengecekan di gang-gang kecil di sekitar kawasan wisata Kota Padang, karena tempat tersebut seringkali digunakan oleh para preman untuk minum minuman keras atau minuman beralkohol. Tindakan tersebut bertujuan untuk pencegahan terhadap preman yang melakukan tindakan premanisme mabuk di muka umum atau pada saat beraktivitas.

Upaya penanggulangan ini merupakan suatu tindakan aktif yang dilakukan oleh pihak berwajib setelah penyimpangan sosial tersebut terjadi, untuk menindak para pelaku sesuai dengan perbuatannya serta memperbaikinya kembali agar mereka sadar bahwa perbuatan yang mereka lakukan adalah perbuatan melawan hukum dan merugikan masyarakat, agar tidak mengulanginya lagi.

Melalui pengertian upaya penanggulangan represif tersebut apabila dikaitkan dengan tindakan premanisme di kawasan wisata Kota Padang, maka tindakan penanggulangan dapat dilakukan dengan cara melaporkan kepada petugas yang sedang bertugas di kawasan wisata Kota Padang apabila terdapat preman yang melakukan tindakan premanisme baik tindakan pemerasan maupun tindakan mabuk di muka umum. Sehingga setelah dilaporkan kepada petugas yang sedang bertugas, preman yang melakukan tindak premanisme tersebut dapat ditangkap dan diberi pembinaan lebih lanjut.

Berdasarkan wawancara yang penulis lakukan, apabila para preman yang melakukan tindakan premanisme telah ditangkap oleh Petugas tersebut, maka akan dibawa ke Kantor Ditpamobvit Polda Sumbar. Para preman yang melakukan tindakan premanisme tersebut akan di data terkait tentang identitas mereka dan kemudian di kumpulkan di lapangan untuk dilakukan pembinaan yang memberikan efek jera kepada para pengamen tersebut. Dalam proses pendataan identitas para preman tersebut, apabila terdapat seorang 
preman yang bukan berasal dari Kota Padang, maka akan dipulangkan kembali ke kota asalnya untuk dilakukan penindakan lebih lanjut oleh pihak yang berwajib dari kota tersebut.

Bentuk-bentuk dari pembinaan yang dilakukan oleh petugas Ditpamobvit tersebut merupakan hukuman fisik yang bersifat nasionalis, bukan merupakan hukuman fisik yang menyakiti tubuh atau mental dari preman tersebut. Alasan petugas menggunakan hukuman fisik yang mengandung unsur nasionalis, agar preman yang melakukan tindak premanisme tersebut tidak hanya takut dan jera untuk melakukan tindakan premanisme lagi, akan tetapi agar terbangun juga sifat nasionalis mereka yang secara tidak langsung dapat menyadarkan pada diri mereka akan tindakan yang baik dan buruk, serta membuat mereka tahu bahwa perbuatan mereka termasuk tindakan melawan peraturan hukum.

Berbagai tindakan tersebut yang dilakukan oleh pihak ditpamobvit untuk menanggulangi secara langsung setelah tindakan premanisme yang dilakukan oleh preman tersebut terjadi. Akan tetapi apabila warga atau wisatawan setelah mengalami tindakan premanisme oleh preman tersebut dan ternyata tidak terdapat petugas yang sedang bertugas di kawasan wisata Kota Padang, maka dapat dilakukannya tindakan secara langsung Penanggulangan dengan cara teguran inilah yang menyerang mental para preman tersebut agar dikemudian hari tidak melakukan tindakan premanisme saat beraktivitas.

\section{Kendala Dan Upaya Untuk Mengatasi Kendala Dalam Penanggulangan Preman Pada Obyek Wisata Di Kota Padang Oleh Pam Obvit Polda Sumbar}

Pada pelaksanaan penanggulangan preman terutama pada kawasan wisata ditemui beberapa kendala. Faktor Penghambat Direktorat Pengamanan Objek Vital Dalam Penanggulangan preman di kawasan objek wisata di Kota Padang Faktor Sumber Daya Manusia/Kurangnya Jumlah Anggota Personil. Pada Pam Wisata dari seluruh anggota yang terbagi bagi masing-masing Bagian dan Satuan guna mencukupi Perbankan yang ada termasuk sektor Pariwisata, SDM maupun Lembaga Negara lainnya yang perlu diawasi.

Salah satu paling penting dikuasai oleh polisi pariwisata harus memiliki kecakapan dalam berkomunikasi dalam bahasa Inggris. Kasubditpam Wisata Polda sumbar mengatakan, di Subdit Pariwisata sendiri hanya memiliki anggota sebanyak 12 personel. Personel tersebut harus menjaga beberapa tempat lokasi wisata di Kota Padang. Untuk 
lokasi wisata di Kota Padang personel Polisi wisata hanya melakukan patroli dan berkerjasama dengan anggota polsek setempat. Dengan jumlah anggota personil hanya sebanyak 12 orang ini tidak memaksimalkan peran dari Pengamanan Objek Vital dalam pengamanan objek wisata terhadap tindak pidana premanisme di kawasan wisata Kota Padang. Koordinasi ini dilakukan apabila terjadi tindak kriminal maka yang menangani kasusnya kewenangan Polsek sesuai dengan tempat peristiwa. Menyiasati kekurangan personel, selain melakukan patroli juga membina pengamanan internal (satpam) yang berada di lokasi tempat wisata.

Kendala yang sering dihadapai oleh penegak hukum khususnya Polisi Pengamanan wisata di Kota Padang dalam pengamanan objek wisata terhadap tindak pidana premanisme adalah kurangnya partisipasi masyarkat atau pun pengelola objek wisata itu sendiri. Masyarakat di sekitar objek wisata di Kota Padang masih kurang kepeduliannya terhadap hukum dalam permasalahan ini dapat dilihat dari minimnya laporan masyarakat terhadap peristiwa tindak pidana yang terjadi khususnya premanisme yang terjadi di objek wisata di Kota Padang. Masyarakat beranggapan bahwa polisi merupakan institusi yang secara kelembagaan bertugas untuk menjaga keamanan dan mengayomi masyarakat. Masyarakat kadangkala tidak mau menyampaikan informasi berkaitan dengan terjadinya tindak pidana pencurian di tempat wisata dengan alasan tidak ingin menjadi saksi karena hal tersebut dapat menyita waktu, biaya dan tenaga serta dapat mengancam keselamatan mereka terutama datangnya dari pelaku tindak pidana pencurian itu sendiri.

Dalam melakukan pengamanan dan penanganan tindak pidana premanisme di tempat-tempat wisata dibutuhkan personil yang seimbang dengan luas wilayah objek wisata yang ada. Berdasarkan uraian tentang hambatan yang ditemui bahwa jumlah SDM personil polisi wisata yang saat ini ada hanya berjumlah 12 personil dianggap tidak seimbang dengan luas wilayah objek wisata yang harus dijaga sehingga perlu penambahan personil dimana setidaknya dalam setiap tempat wisata dijaga oleh 3 sampai 4 orang polisi wisata sehingga tidak menghambat proses pengamanan apabila terjadi tindak kriminal khususnya kasus premanisme. Terlebih apabila pelaku tindak pidana premanisme tersebut berjumlah banyak. Selain itu upaya untuk meningkatkan kemampuan sumberdaya manusia dapat dilakukan dengan beberapa pendekatan. Salah satu diantaranya adalah metode 
workshop. Dalam hal peningkatan kemampuan, baik pengetahuan dan ketrampilan, maka metode workshop juga sangat tepat untuk digunakan.

Partisipasi masyarakat dalam mewujudkan atau terciptanya suatu penegakan hukum sangat di perlukan demi tegak dan berfungsinya hukum secara nyata di dalam masyarakat, dalam penegakan hukum terhadap premanisme. Dalam hal mengungkap suatu kasus yang berbau premanisme harus adanya suatu laporan dari pihak korban sendiri agar pihak kepolisian mengetahui telah terjadi aksi premanisme, kebanyakan kejadian pemerasan dan kekerasan.

Memberikan satu pemahaman kepada masyarakat Padang dan sekitarnya, bahwa pariwisata adalah milik semua warga. Menjaga dan melestarikan serta ikut dalam proses pemulihan citra pariwisata adalah kewajiban semua warga Padang. Kebanyakan kejadian premanisme yang terjadi tidak di laporkan kepada pihak kepolisian karena tidak ingin berurusan dengan pihak kepolisian dan korban merasa apabila berurusan dengan pihak kepolisian tidak akan menyelesaikan masalah mereka, selain itu korban beranggapan apabila kasusnya di laporkan dengan kepolisian maka akan mengeluarkan biaya lagi untuk memproses kasus mereka dan juga mereka merasa repot dengan penanganan di Kepolisian karena melihat aksi premanisme yang sudah pernah melaporkan kasus mereka kebanyakan yang tidak selesai atau terkesan lambat dalam penanganannya, dengan adanya anggapan masyarakat terhadap penegak hukum, tentu hal ini menjadi kendala bagi penegak hukum dalam menjalankan tugasnya, penegak hukum membutuhkan partisipasi masyarakat demi mengurangi tingkat aksi premanisme di tempat tempat objek wisata di Kota Padang.

Upaya dilakukan untuk menanggulangi tindak pidana secara optimal, pendekatan yang perlu dilakukan adalah dengan melakukan pendekatan sistem pertanggungjawaban pidana sebagai salah satu kebijakan kriminalisasi. Kebijakan kriminalisasi sebagai usahausaha yang rasional untuk mengendalikan kejahatan problem sosial yang dinamakan kejahatan dapat dilakukan dengan berbagai cara. Sudah barang tentu tidak hanya dengan menggunakan sarana penal (hukum pidana) tetapi dapat juga dengan menggunakan sarana-sarana non penal. Penanggulangan kejahatan dengan sarana hukum pidana berarti mengadakan pemilihan untuk pencapaian hasil perundangan pidana yang paling baik dalam arti memenuhi syarat keadilan dan daya guna. 
Implementasi dari program penguatan dengan lintas sektoralyang salah satunya dilakukan melalui penggelaran fungsi sinergi polisional untuk mengeliminasi problem peripheral, yaitu potensi persoalan yang patut diduga akan menjadi masalah keamanan dan ketertiban bila tidak ditangani dengan baik, sebagai fenomena residual yang mengendap di berbagai bidang pemerintahan dan kemasyarakatan. Fungsi sinergi polisional sebagai implementasi proactive policing dilakukan dalam bentuk kegiatan melalui fungsi audiensi, mediasi, asistensi, elaborasi, advokasi, koordinasi, dan transkripsi.

Community dan problem oriented policing diartikan bahwa adanya usaha kolaburasi antara polisi dan masyarakat melalui sinergitas polisional dimana kedua-duanya bersama-sama mengidentifikasi dan memecahkan terhadap terjadinya permasalahanpermasalah ditengah-tengah masyarakat dan faktor penyebab terjadinya gangguan keamanan dan ketertiban masyarakat sehingga ambang gangguan dapat diantisipasi, tidak menjadi potensi gangguan dan gangguan nyata.

Hal yang paling utama dalam penerapannya adalah dengan mengetahui permasalahan sosial yang ada dan sedang terjadi, untuk itu diharapkan Polri mampu untuk membaca perkembangan lingkungan dengan berbagai perubahannya guna dapat mengantisipasi segala bentuk kejahatan yang dilakukan oleh premanisme dan permasalahan-permasalahan yang mengakibatkan gangguan keamanan dan ketertiban masyarakat. Salah satu kegiatan yang berorientasi pada community orientied policing dan problem oriented policing adalah mengaplikasikan langkah-langkah problem oriented policing dalam kerangka penanggulangan gangguan Kamtibmas termasuk premanisme. Adapun langkah-langkah yang dilakukan dengan tahapan-tahapan sebagai berikut: Pertama, Forum Dialog. Yaitu kegiatan untuk memecahkan setiap permasalahan yang terjadi ditengah-tengah masyarakat termasuk permasalahan terjadinya premanisme jalanan yang berdampak pada rasa aman masyarakat untuk mencari solusi dalam pemecahannya dengan melibatkan partispasi aktif masyarakat maupun lintas sektoral. Dari hasil dialog dan solusi yang telah ditemukan diharapkan adanya Nota Kesepahaman tokoh masyarakat dan lintas sektoral yang selanjutnya dilakukan pengawasan atas pelaksanaan kesepakatan tersebut. Kedua, pengendalian Kesepakatan atas permasalahan yang telah ditemukan solusinya. Nota kesepakatan yang telah dibuat, disepakati dan ditandatangani oleh perwakilan tokoh-tokoh masyarakat. Dalam pelaksanaan nota kesepakatan tersebut, 
dilakukan pengawasan dan dikendalikan oleh seluruh masyarakat, terutama oleh para tokoh.

Padang sebagai Ibu Kota Provinsi Sumatera Barat dengan tingkat kriminalitas khususnya premanisme yang tinggi. Terlebih tindak krimnalitas premanisme yang terjadi di objek-objek wisata yang ada di Kota Padang. Tingkat perekonomian masyarakat yang semakin meningkat yang dapat di lihat dengan semakin banyaknya pembangunan. Seiring perkembangan zaman, Padang mengalami pula berbagai macam permasalahan sosial dan politik akibat krisis ekonomi serta menurunnya tingkat kepercayaan masyarakat terhadap pelaksanaan pembangunan, baik aparatur pemerintah maupun pelaku dunia usaha, dan permasalahan kemiskinan sampai tindakan kriminal yang dilakukan oleh para pelaku premanisme. Premanisme merupakan salah satu bentuk dari perilaku menyimpang. Kondisi pelaku premanisme sering kali dapat dipengaruhi oleh tingkat perekonomian, pendidikan serta iman yang lemah sehingga dengan mudah melakukan tindak kejahatan.

Tingginya tingkat kejahatan yang didahului dengan aksi premanisme yang terjadi merupakan ancaman dan tantangan terhadap keamanan dan ketertiban masyarakat, yang pada gilirannnya menghambat usaha usaha pembangunan untuk mencapai kesejahteraan masyarakat. Akibat sering terjadinya premanisme di tempat wisata yang ada di Kota Padang inilah menyebabkan adanya krisis kepercayaan masyarakat, banyak pihak resah dan takut, sehingga enggan untuk mengunjungi tempat-tempat wisata yang ada di Kota Padang.

Berdasarkan wawancara penulis dengan salah seorang pengelola tempat wisata di Kota Padang, disebutkan bahwa, pengamanan yang dilakukan oleh jajaran Ditpamwisata sangat membantu pengelola tempat wisata, karena para pengungjung merasa aman dan nyaman dan tidak merasa khawatir terhadap keamanan dirinya maupun kendaraan yang digunakan pengungjung dari tindak kejahatan.

Banyak faktor yang dapat mendukung terciptanya sebuah kenyamanan para wisatawan di obyek wisata yang mereka kunjungi. Selain kualitas pelayanan, faktor keamanan adalah satu faktor yang paling dapat dirasakan oleh wisatawan. Faktor keamanan merupakan tingkat gangguan/kerawanan keamanan terhadap pengunjung disuatu obyek wisata, karena faktor keamanan akan mempengaruhi ketenangan dan kenyamanan wisatawan selama berada di obyek wisata tersebut, disamping itu faktor keamanan tersebut 
juga akan mempengaruhi wisatawan dalam mengambil keputusan layak atau tidak obyek wisata alam tersebut untuk dikunjungi. Kota Padang masuk dalam destinasi favorit wisatawan, untuk itu menjaga keamanan dan kenyamanan pengunjung adalah hal yang utama. Misalkan dengan menyediakan pengaman obyek wisata khusus, tujuan untuk memberikan informasi tentang hal-hal yang terkait dengan kondisi dan keamanan kawasan. Memberikan rambu-rambu dan papan informasi di tempat yang rawan gangguan keamanan, melengkapi sarana prasarana alat komunikasi juga dapat menjadi pendukung keamanan di suatu obyek wisata.

\section{PENUTUP}

Penanggulangan Preman Pada Obyek Wisata Di Kota Padang Oleh Pam Obvit Polda Sumbar dilakukan dengan cara melakukan razia atau pemeriksaan oleh petugas kawasan wisata Kota Padang. Para petugas dalam melakukan razia tersebut, tidak dilakukan secara "sidak" atau inspeksi mendadak, akan tetapi dalam melakukan kegiatan razia para petugas melakukannya secara rutin setiap hari, menyampaikan himbauan kepada masyarakat melalui pengeras suara yang intinya berbunyi bahwa masyarakat tidak boleh memberikan uang kepada preman, Kendala Dalam Penanggulangan Preman Pada Obyek Wisata Di Kota Padang Oleh Pam Obvit Polda Sumbar adalah faktor sumber daya manusia/kurangnya jumlah anggota personil, kurangnya partisipasi masyarakat/pengelola objek wisata.

\section{DAFTAR PUSTAKA}

\section{Buku Teks:}

Abintoro Prakoso, Kriminologi dan Hukum Pidana, Laksbang Grafika, 2013, Yogyakarta

Muladi dan Barda Nawawi Arif, Teori dan kebijakan Hukum Pidana, Alumni, Bandung, 1984, hlm 158

Wahju Muljono, Pengantar Teori Kriminologi, Pustaka Yustisia, Yogyakarta, 2012

\section{Peraturan Undang-Undang :}

Peraturan Kepala Kepolisian Negara Republik Indonesia Nomor 22 Tahun 2010 tentang Susunan Organisasi Dan Tata Kerja Pada Tingkat Kepolisian Daerah. 